DOI: $10.33067 /$ SE.2.2020.2

Melania-Gabriela Ciot *

Iulia-Anamaria Ghidiu ${ }^{\star}$

\title{
Reconfiguration of Geopolitical Strategies in Trump's Era: The Impact of American Political Leadership's Idiosyncrasies on the Traditional Transatlantic Relations
}

\begin{abstract}
The International System is traversing a challenging stage in its evolution. The United States should carefully consider the risks of an idiosyncratic leadership and closely work with their European partners, securing a world order based on the norms of multilateralism and democracy. Still, the US President Donald Trump unveils an approach based on emotional and synchronous elements. As a matter of consequence, the EU is considering other geopolitical alternatives to accomplish its goals and deliver the best outcome to the people it serves and for global prosperity. The paper investigates the very specific psychological factors influencing Trumpian political thinking and justifying his corresponding foreign policy decisionmaking processes, in the current transatlantic environment. By contextual examples, the analysis reveals the sensitivities and flaws in applying a subjective, belief-based approach of international (bilateral) relations. We put things into a broader perspective, by analysing the implications of such political behaviour patterns for the international liberal order, in the circumstances of the more and more prominent geopolitical triangle: the EU-China-the US.
\end{abstract}

Keywords: Donald Trump, Idiosyncratic Leadership, Cognitive Approach, Transatlantic Alliance, Geopolitical Alternatives

\footnotetext{
^ Melania-Gabriela Ciot - Babeş-Bolyai University, Cluj-Napoca, e-mail: Gabriela. Ciot@ubbcluj.ro, ORCID: 0000-0003-2531-0606.

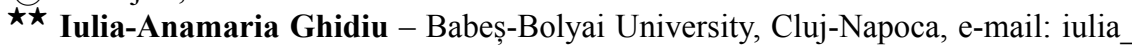
anamaria_g@yahoo.com, ORCID: 0000-0001-8734-3249.
} 


\section{Introduction}

The psychological approaches define a series of modern theories, complementary to the classical models of decision-making (the rational actor, the organizational behaviour and the governmental policies' models), useful when examining the inner driving forces of a particular individual or decision-making group, involved in a specific political context. The cognitive approach and groupthink represent the two types of psychological approaches, bearing similar framing tendencies, on the basis of a distorted, limited, self-censored and stereotyped content, with reference to actors and events outside the comfort zone of the subjective or like-minded decision makers. The advisory system as a practice of groupthink is best exemplified by the American presidential institution and the Trump administration makes no exception from the rule. Psychological perspectives will be discussed in detail in the first part of this paper, entitled Understanding the businessman-like Trumpian idiosyncratic legacy: a psychological analysis of the current American political leadership.

In the second part, Framing new models of political decision-making in the current transatlantic context, we explore how the traditional transatlantic alliance has been slowly decreasing in power and influence as a collective, global actor, displaying gradual signs of implosion. Tensions escalated especially as President Donald Trump popularized his protectionist, populist view on the future of the American society and a sceptical, transactional attitude towards the European Union, respectively, seen through the lens of rival, a competitor "very tough to deal with". Personal characteristics, inherited business skills and deeply rooted, stereotyped beliefs played a significant role in the political process of decision-making. This attitude has in fact pushed Europeans to detach, both mentally and practically, from the cooperation and partnering prospects with the US. They took steps to develop as a strategically autonomous political entity, aiming to become a more powerful voice at international level, on their own, without relying on American engagement anymore.

With China on the rise, both the EU and the US face a real, common counter-candidate to the global leadership position. They have each secured bilateral commitment involving Beijing, while largely disregarding a potential renewal of the talks in "the Western hemisphere", for months on end. This shift of paradigm has many chances to convert the main geopolitical trends of the current world order, while at the same time weakening the transatlantic pillar of liberal values. The coronavirus pandemic adds a new dimension to this already complex picture, positioning China in a quite controversial context, impacting upon further 
openness from the Western partners. These aspects are being investigated in the last part of the article, subtitled Reconfiguring geopolitics: strategies to adjust EU's and US' foreign relations with China in the new transatlantic environment.

\section{Understanding the Businessman-like Trumpian Idiosyncratic Legacy: A Psychological Analysis of the Current American Political Leadership}

Rational and stable political leadership is one of the main pillars on which a society is based. However, it cannot be overlooked the fact that emotions too can play a significant role in shaping the leadership style a prominent political figure adopts. The decision-making process can be easily influenced by many (internal and external) factors. Psychological factors account for a complex and well-defined category of inner elements impacting upon national political strategies to a considerable extent. Among these, experts have included factors such as personality traits or the leaders' set of beliefs, emotions, images, cognitive consistency, the use of analogies, intelligence and how all these influence the decision-making process and the expected outcome. ${ }^{1}$

Richard Fagen differentiated between two styles of decision-making in foreign policy: calculated and emotional. ${ }^{2}$ Falling into the second category, idiosyncrasies (personal, social factors) ${ }^{3}$ can lead to more complexrealistic approaches of decision-making, compared to the "classical" rational model. They bring a personal mixture of internal and external factors into foreign policy decisions-making, capable of influencing the course of an action. ${ }^{4}$

Analysing Donald Trump's idiosyncratic profile has been a delight for many political scientists and psychologists, as well as international relations experts. With a surprising turnaround when it comes to the leadership style he adopted, the US president has undoubtedly encouraged a new paradigm to discuss transatlantic relations, as personal convictions

1 M.G. Ciot, Negotiation and Foreign Policy Decision-Making, Cambridge Scholars, Newcastle upon Tyne 2014, p. 182.

2 R.F. Fagen, Calculation and emotion in foreign policy: the Cuban Case, "Journal of Conflict Resolution", vol. VI, no. 3/1962, pp. 214-221.

3 F. Campanale, B. Shakun, Behavioral Idiosyncracies and How They May Affect Investment Decision, "American Association of Individual Investors Journal", vol. XIX, no. 9/1997, pp. 13-17.

4 M.G. Ciot, Idiosyncrasies In Trump’s Foreign Policy Decision Making, in: Analele Universităţii din Oradea, ed. M. Brie, University of Oradea, Oradea 2016, p. 44. 
and specific framing of Europeans' behaviour determined Trump to assess the longstanding partnership into a "tit-for-tat" competition framework and, therefore, to initiate radical actions that cast doubt about the steadiness of American engagement in European and international affairs. Consequently, the EU member states found themselves in the need to reconfigure geopolitical and foreign relations' priorities and to look more at their own capacities, vulnerabilities and opportunities that lie ahead, even related to third parties (other international actors).

One of the most complex analyses regarding the psychological profile of Donald Trump belongs to Dan P. McAdams, a prestigious author, wellknown for his fine profiling of American presidents (Reagan, Bush Jr.). Investigating personality, developmental and social psychology elements, in his article entitled The Mind of Donald Trump, he identified the main personality characteristics, that will have had a significant impact on his presidency: narcissism, disagreeableness and grandiosity. McAdams wrote: "Trump seems supremely cognizant of the fact that he is always acting. He moves through life like a man who knows he is always being observed. If all human beings are, by their very nature, social actors, then Donald Trump seems to be more so-superhuman, in this one primal sense". ${ }^{5}$

McAdams analysed his dispositions, cognitive styles, motivation and self-conceptions, all four aspects being relevant in defining the leader's idiosyncrasies. Basically, these features will define a psychological model of decision-making, exploiting the tendencies that are specific to the cognitive approach and that will be discussed and exemplified in the second part of the paper. Based on the Big Five theory of personality, McAdams distinguished between the following categories: Extroversion, Neuroticism, Conscientiousness, Agreeableness and Openness. On a particular note, McAdams noticed that President Donald Trump shows a "sky-high extroversion combined with off-the-chart low agreeableness".

Dispositions offer us clues in defining and understanding a leader's decision-making style. Particularly speaking, extroverts tend to take high-stakes risks and people with low levels of openness rarely question their deepest convictions. As a real-estate developer, we can say that he has taken big risks, and it is the case in Trumpian politics too, trying to deliver big payoffs (i.e. to Make America Great Again! - as his campaign slogan goes. "I find the people who are the best in the world at what needs

5 D.P. McAdams, The Mind of Donald Trump, "The Atlantic", 2016, http://www. theatlantic.com/magazine/archive/2016/06/the-mind-of-donald-trump/480771/ (access 14.03.2020). 
to be done, then I hire them to do it, and then I let them do it... but I always watch over them"6).

Regarding mental habits, The Art of a Deal by Donald Trump advices on how to start a negotiation from a position of strength, and the concept of "deal" represents a personalized schema ("a way of knowing the world that permeates his thoughts"), ${ }^{7}$ informing us about the decisionmaking style he prefers, even in politics. Trump is focusing on personal relationships and one-on-one negotiating tactics, another strong indicator for an idiosyncratic approach of the position he occupies.

Discussing motivations, we investigate further beyond President's narcissism, to uncover what are his goals. McAdams noticed the most important goal of a narcissistic person is to love himself and to be loved by others, "to promote the greatness of the self, for all to see" - and this can be exemplified by the US leader's initiative to put his name on his buildings, books, university and TV shows. "Narcissism undoubtedly is a general description of President Trump's personality, but it is not a psychiatric disorder by itself", adds British doctor David Owen, in his book entitled Hubris, the road to Donald Trump. Power, populism and narcissism. ${ }^{9}$

One of the representations of American presidents comes from the narrative, namely the stories about themselves, from where they exert moral elements and frame a nation-defining legacy, McAdams argues. From a psychological point of view, narrative identities "explain how they came to be who they are". ${ }^{10}$ The Trumpian narrative, in his own acceptation, "expresses nothing like Bush's gentle nostalgia or Obama's curiosity, but a sense of danger and a need for toughness: The world cannot be trusted". ${ }^{11}$

Approaching politics with a businessman mindset, centered on his own person, has offered us important information about future decisional steps. We identified the presence of emotional (Negative Emotions), motivational (Self-Realization, Responsibility) and social perception (Self, Others) idiosyncrasies of Trump. ${ }^{12}$ The way in which his election campaign was designed also delivered the message that we are facing an idiosyncratic leader, who will base his decisions on emotional grounds.

6 D.J. Trump, Great Again: How to Fix Our Crippled America, Threshold Editions, Reprint edition 2016, p. 16.

7 D.P. McAdams, op. cit.

8 Ibidem.

9 D. Owen, Hubris, the road to Donald Trump. Power, populism and narcissism, Methuen, York 2018, p. 15.

${ }_{10}$ McAdams, op. cit.

11 Ibidem.

12 M.G. Ciot, Negotiation..., pp. 183, 192-193, 196-197, 199. 


\section{Framing New Models of Political Decision-Making in the Current Transatlantic Context}

The US relation with the EU is one of the controversial subjects falling under a new Trumpian political doctrine. The bilateral relation has suffered visible transformations because of a different framing involving the psychological (cognitive) approach elements in the decision-making process, influenced by populist and protectionist viewpoints, personal beliefs of the US leader, because of various historical analogies regarding the American destiny in the world and on its very own territory.

As Donald Trump took office at the White House, publicly expressed messages started to worry its overseas partners. Engaged in an enduring blame game, he viewed the US as a historically altruistic nation, motivating US' failures in a defensive manner (cognitive distortion): "For many decades, we've enriched foreign industry at the expense of American industry, subsidized the armies of other countries, while allowing for the very sad depletion of our military. We've defended other nation's borders while refusing to defend our own. (...) No region has benefited more from U.S. security guarantees since World War II than Europe". ${ }^{13}$

Out of the "America First" strategy, trade tensions arouse on multiple fronts, between the US and states like China, Canada, Mexico or Japan, ${ }^{14}$ but the EU was nonetheless a major source of dispute for the current administration. The US president erroneously framed it an enemy or, at least, a fierce competitor, "very tough to deal with" because it had "taken advantage" of the U.S. (cognitive distortion). This perception clearly impacted upon his foreign policy decisions and corresponding actions to implement them.

As the EU imposed several agricultural trade barriers on US exports to the continent, this became a serious impediment for President Trump's engagement in comprehensive commercial relations with Europe: "Europe has been treating us very badly," Trump said. "Over the last 10, 12 years, there's been a tremendous deficit with Europe. They have barriers that are incredible...". ${ }^{15}$ The need for retaliation thus came as a natural thing, in

${ }_{13}$ M. Karnitschnig, Donald Trump leaves Europe in the cold, „Politico”, 20.01.2017, http:/www.politico.eu/article/donald-trump-leaves-europe-in-the-cold-in-inauguration/ (access 14.03.2020).

14 R. Noack, Now that Trump has a trade deal with China, some Europeans fear he will focus his trade threats on them, "Washington Post", 17.01.2020, https://www.washingtonpost.com/world/2020/01/17/now-that-trump-has-trade-deal-with-china-some-europeans-fear-he-will-focus-his-trade-threats-them/ (access 14.03.2020).

15 A. Shalal, D. Lawder, As Trump takes aim at EU trade, European officials brace for fight, „Reuters”, 11.02.2020, https://www.reuters.com/article/us-usa-trade-europe-analy- 
President Trump's acceptation, largely ignoring medium and long-term consequences over the future of the transatlantic partnership (not putting things into perspective-cognitive distortions).

The narrative in which the EU is seen as a threat to American national interest (or security) proved to be a harmful discourse for transatlantic relations. Phil Hogan, European Commissioner for Trade said that "we reject the U.S. labelling the E.U. as a security risk in order to justify the imposition of tariffs" as "the narrative is hurtful to our European people". ${ }^{16}$

After many months of longstanding tensions, the two blocks proved willing to conclude a deal as soon as possible, covering trade, technology and energy. "I am looking forward to working with President Trump on the opportunities and challenges ahead of us. I am convinced that we can engage in a positive US-EU agenda in trade, as well as on technology, energy and much more besides", ${ }^{17}$ Ursula von der Leyen, president of the European Commission declared on the occasion of her bilateral meeting with the US President on the margins of World Economic Forum in Davos, in January 2020. "We've been talking about it for a while, and hopefully we can get something done", ${ }^{18}$ Trump responded, nevertheless reiterating the validity of punishing levies on the European automotive sector.

Moreover, thinking of the remaining controversial aspects, Hosuk Lee-Makiyama, director of the European Center for International Political Economy, suggested that the course of reaching a commercial deal with the Europeans can be quite tough for the US "since the new commission in Europe has very little policy space to offer the Americans any concessions, whether it's agriculture or civil aircraft or taxes...". ${ }^{19}$

After a series of ups and downs in the past year in bilateral US-China trade relations, concluding a Phase-One deal with Beijing on January 15, 2020 made Europeans fear Trump's disinterest in striking a deal with the EU, especially as the last year in December U.S. Trade Representative

sis/as-trump-takes-aim-at-eu-trade-european-officials-brace-for-fight-idUSKBN2051AK (access 12.03.2020).

${ }^{16}$ P. Hogan, Refreshing Transatlantic Trade Relations, Keynote Address at Centre for Strategic and International Studies (CSIS), Washington DC, 16.01.2020, http://ec.europa. eu/commission/commissioners/2019-2024/hogan/announcements/refreshing-transatlantic-relations-keynote-address-commissioner-phil-hogan-centre-strategic-and_en (access 12.03.2020).

17 B. Rios, Von der Leyen and Trump fine tune transatlantic relations in Davos, „Euractiv", 21.01.2020, http://www.euractiv.com/section/economy-jobs/news/von-der-leyenand-trump-fine-tune-transatlantic-relations-in-davos/ (access 12.03.2020).

${ }^{18}$ Ibidem.

19 R. Noack, op. cit. 
Robert Lighthizer spoke about their "very unbalanced" trade relationship with Europe, a potential trend of Washington's focus in 2020.

Other erroneous convictions like "NATO is obsolete" caused additional unrest among European partners by suggesting the hypothesis of America withdrawing from NATO, an impulsive decision which would mean a de facto dissolution of the North-Atlantic Alliance.

The famous slogan, popular during President Trump's campaign, Make America Great Again!, takes us back in time by means of historical analogies, if we consider the imperialist and elitist view on the American destiny, restoring its traditional superiority and uniqueness. This tendency of motivation by using or implying historical examples or previous successful policies was defined as a cognitive shortcut, often impeding decision-makers in conducting a sensitive thinking process.

Another highly important feature of the American political decisionmaking model relies on the traditional, very specific groupthink ${ }^{20}$, exemplified by the advisory system ${ }^{21}$ acting close to the US president and trying to bring their contribution to a particular decision regarding national security and foreign policy matters. The tradition of the Cabinet can be traced back to the beginnings of the Presidency itself. It was established by Article II, section 2 of the US Constitution ${ }^{22}$. Throughout time, the advisory system has been observed as a practice in American presidential history, with both successful (Nixon-Kissinger, Bush-Scowcroft or Wilson-House cooperation) and unsuccessful records (see, for instance, Pearl Harbor-the American Commander group believed that the Japanese won't ever risk attacking the US, the admiral joking about the situation). ${ }^{23}$

President Trump has been subject to criticisms for gathering as senior advisers a like-minded, "camera-ready" crew, with scarce policy experience (although he seemed not to pay significant attention or listen to those around him at all times). It is the case, for example, with Lary Kudlow, president's chief economic adviser and former TV host. Kudlow supported the US-China deal, as he called it a "historic" and unprecedented agreement. ${ }^{24}$

20 P.A. Kowert, Groupthink or Deadlock: When Do Leaders Learn from Their Advisors?, State University of New York Press, Albany, NY 2002.

${ }_{21}$ T. Preston, The President and His Inner Circle: Leadership Style and the Advisory Process in Foreign Affairs, Columbia University Press, New York 2001.

22 J. Shallus, The Constitution of the United States: A Transcription, https://www. archives.gov/founding-docs/constitution-transcript (access 21.03.2020).

${ }^{23}$ R. Jackson, G. Sorensen, Introduction to International Relations. Theories and approaches, Oxford University Press, Oxford 2007, p. 235.

24 T. Kaplan, Kudlow: Phase One of China trade deal is 'historic' and will help US economy grow faster, "FoxNews", 15.01.2020, https://www.foxnews.com/media/larrykudlow-china-trade-deal-defends-american-economy (access 21.03.2020). 
Peter Navarro, Trump's top trade advisor argued forcefully against any bilateral commercial deal with China and pressed for stiff tariffs to be imposed on this country, going beyond the objections raised by fellow advisers, ironically regarded as "globalists". Trump followed suit on dealing with China, although he empathised with Navarro's tough view on Beijing's growing influence and accepted to impose severe tariffs on Chinese products. "The deal with China is a massive deal", Trump affirmed, adding: "No, I'm not a globalist" ${ }^{25}$ His trade adviser gradually managed to influence Donald Trump on other foreign policy issues like NAFTA (now USMCA), after repeated opposition from other senior officials, among which Gary D. Cohn, the former head of the US National Economic Council, blocking several attempts to trigger the NAFTA withdrawal process.

On transatlantic trade (see the politically dead TTIP), Navarro saw Germany as one of the main hurdles to a US trade deal with the EU, using a "grossly undervalued" euro to "exploit" the US and its EU partners. ${ }^{26}$ More recently, Wilbur Ross, US Secretary of Commerce, was at best optimistic about the possibility of concluding a deal with the Europeans in 2020 and he believes trade talks can produce a deal before duties on vehicles are needed to be applied. "The president simply said this is, 'If it fails,' where our working assumption is it will not fail and that we will make a deal with them" (n.n.the EU). ${ }^{27}$ Still, it is not a tragedy if the deal does not materialise, showing a sense of empathy for President Trump's alternative to impose additional tariffs: "But if not, the President is totally comfortable going the other direction". ${ }^{28}$

Former US national security advisor Michael Flynn acknowledged for ACB News having tried to shape President Trump's view on NATO. "We did talk about NATO, and I told him ... NATO doesn't pay their bills. (...) NATO is a 20th century model and needs to be retooled for $21 \mathrm{st}$ century threats that we collectively face. You know, cyber is one of them.

25 A. Rappeport, A. Swanson, Peter Navarro, Trump's Trade Warrior, Has Not Made His Peace With China, "The New York Times", 26.12.2019, https:/www.nytimes. com/2019/12/26/us/politics/peter-navarro-china-trade.html (access 21.03.2020).

26 S. Donnan, Trump's top trade adviser accuses Germany of currency exploitation, "Financial Times", 31.01.2017, https://www.ft.com/content/57f104d2-e742-11e6-893c082c54a7f539 (access 21.03.2020).

27 J. Garber, J. Langford, Europe has 'sense of panic' over securing US trade deal: Wilbur Ross, „Fox Business”, 23.01.2020, https://www.foxbusiness.com/markets/us-europe-trade-deal-wilbur-ross (access 21.03.2020).

28 S. Amaro, It's 'complicated to negotiate with the European Union,' Wilbur Ross says, "CNBC", 17.06.2019, https://www.cnbc.com/2019/06/17/its-complicated-to-negotiate-with-the-eu-wilbur-ross-says.html (access 21.03.2020). 
So I said those things to him when we first talked". ${ }^{29}$ On the contrary, former senior adviser John Bolton, who also served in the administration of President George W. Bush, warned about the negative consequences of Trump's allegations on NATO.

In November 2018, in an interview for Fox News Sunday, Trump summarized his view on the actual decision-making process and on the advisory team he owns, whom he described as "talented", but at the same time internally competitive, providing him information on which he bases his decisions, nevertheless considering what he feels is "the right way forward": "I don't think about, you know, how I make'em. I make what I consider the right decision, I have some tremendously talented people and I will talk to them and sometimes I'll have them go at each other, I do like that (...). They've very competitive people and at the end I make a decision and it's certainly - on the economy, a lot of things we've been - we've made a lot of good decisions and I want to keep it that way". 30

\section{Reconfiguring Geopolitics: Strategies to Adjust EU's and US' Foreign Relations with China in the New Transatlantic Environment}

The Chinese factor could become very prominent in the next years and the triangle EU-China-US could easily become a very interesting reality, in the sense of additional, bidirectional interdependencies. It has already prefigurated as a quite influential - and sometimes controversial - geopolitical game field, if we take into consideration the oscillating, discontinuing but nevertheless appealing ties between the EU and China and the US and China, respectively.

The recent trend of the events leads us to a sad but realistic conclusion: the transatlantic relation is on the verge of losing ground in front of a new configuration of global interactions, a geopolitical network where China (and it may not be the only one) manages to impose itself more and more as an emerging global actor, gaining credibility and an increasing rate of commercial and high-technology success amidst European and American

29 J. Fishel, Mike Flynn Says He Helped Shape Trump's Views on NATO, “ABC News", 19.11.2016, https://abcnews.go.com/Politics/mike-flynn-helped-shape-trumpsviews-nato/story? $\mathrm{id}=43642585$ (access 21.03.2020).

30 J. Lucas, U.S. President Donald Trump on his decision-making process: "I don 't think about it”, ,The Georgia Straight”, 19.11.2018, https://www.straight.com/news/1166066/ us-president-donald-trump-his-decision-making-process-i-dont-think-about-it (access 21.03.2020). 
strategic partners. The latest crisis we are traversing after the rapid spread of the coronavirus infection has nevertheless introduced a risky element in trilateral networking, seemingly disrupting transatlantic engagement more and more and raising a question mark on China's goodwill and partnering stability. But let us have a look at the situation before this biological threat entered the international community's focus.

A common feature in their bilateral relation with Beijing is that both the EU and the US are constantly keeping an eye on each other's openness to China. The lower the mutual engagements, the higher the chances for Brussels and Washington to sit at the negotiation table, it appears. China appears as an attraction for both but, at the same time, it can devastate the two's status on the world economic spectrum, if too much influence is being credited in the form of apparently harmless or mutually beneficial Chinese investments in Europe and the United States. The gap in transatlantic cooperation-considerably due to the new idiosyncratic leadership approach in Washington- is a fertile ground for new actors to gather sympathy and to present their strategic offer as more convenient, while further disengagement can be also entertained by the EU and/or US "open-door policy" towards third parties (to an extent that might deliver fear and instability over transatlantic affairs).

Though the former European Commission impressed by labelling China as "a strategic competitor" or "a systemic rival", the new executive led by Ursula von der Leyen seems to think in another geopolitical paradigm, much less confrontational. A pending common EU strategy towards Beijing accounts for a challenging enterprise to adjust preferences and to join forces, for the most reasonable and satisfactory outcome.

In the last months, individual states' position towards China has suffered a visible shift of paradigm, notwithstanding national controversies in "internal opposing camps" (see, for instance, Germany's and UK's tendency to embrace the next-generation technology developed by telecommunications giant Huawei, or German Chancellor Angela Merkel's hardcore optimism about the EU and China concluding a comprehensive investment agreement in time for the bilateral summit in Leipzig, September 2020). ${ }^{31}$

A landmark in EU-Chinese bilateralism is, of course, the Belt and Road Initiative, launched in 2013, through which Beijing aims to attract as many partner countries from around the globe as possible, in an ample infrastructure investment program, paving the route for the new SILK ROAD diplomacy

${ }^{31}$ N. Barkin, Europe's moment of truth with China. 6 factors that will shape the Continent's relationship with Beijing in 2020, "Politico", 13.01.2020, https://www.politico.eu/ article/europes-moment-of-truth-with-china-trade-eu/ (access 13.03.2020). 
(or the corridor denominated The New Eurasian Land Bridge-connecting Western China to Western Russia, for our particular discussion). Though long debated within European political circles, the EU as a whole did not come up with a unified response to this challenging proposal, weighing up carefully all the advantages and disadvantages it entails.

On a balanced perspective, the megaproject received both applause and criticism in Europe. The latter was mostly related to Beijing's perceived strategy to rewrite global rules and rejoice about global dominance by means of investing in and supporting industrial and high-tech innovations' development, defying the international multilateral standards, while threatening EU's (perhaps primary) geo-economic sovereignty and internal unity, by influencing individual EU countries to step into the game.

Thus, BRI's growing appeal might be considered a vital moment in EU's geopolitics, when the axis actually started to move sides, as countries joined one by one the strategic initiative (embracing the " $16+1$ " offer), signing bilateral, BRI-related cooperation agreements, and EU-based financial institutions like ERBD or EIB and European companies (see DHL, Siemens) followed the same pattern. ${ }^{32}$

As expected, the US disregard EU intertwining with China and have fears about the broader BRI prospects. The Shanghai Cooperation Organization gradually came to be perceived as a potential counter candidate for NATO, that has already rendered its ties with the UN, the CIS, ASEAN, the Eurasian Economic Community as official and, respectively, the Collective Security Treaty Organization. ${ }^{33}$ More recently, Washington has repeatedly warned Europe about the underlying effects of accepting China's 5G technological supremacy, stressing that the vision should be much broader and not limited to the opportunity in itselfa price-worthy alternative to competing offerings-, as such move could be a proper way for Beijing to gain influence at global level, considering its overall, growing commercial, technological and military expansion in the last period. But until the U.S. can offer Europeans a viable alternative to Huawei (a Trojan horse on the European continent ${ }^{34}$ ), the Chinese option is likely to remain unchallenged.

${ }^{32}$ A. Skala-Kuhmann, European Responses to BRI, An overdue assessment, „HorizonsJournal of International Relations and Sustainable Development”, no. 14/2019, p. 150.

33 See I.A. Ghidiu, Reinventarea Drumului Mătăsii, ,Economistul”, 28.09.2016, https:// www.economistul.ro/cover/reinventarea-drumului-matasii-733/ (access 13.03.2020).

${ }^{34}$ M. Karnitschnig, Europe turns deaf ear to US warnings on Chinese 5G. Washington warns its allies that Huawei is a Trojan horse for Beijing's expansion plans, „Politico”, 15.02.2020, https://www.politico.eu/article/u-s-chides-europe-on-china-tech-risks/ (access 13.03.2020). 
"I continue to stress to my friends in Europe ... that America's concerns about Beijing's commercial and military expansion should be their concerns as well", U.S. Defense Secretary Mark Esper told the audience at the Munich Security Conference in February 2020, a powerful symbol of the Western alliance's geopolitical strength and stability. In the US official's view, the problem lies in the differing perception (of Europeans and Americans, respectively) of the threat posed by China in shaping a new world order.

However, Washington has managed to secure the first phase of the 2020 Economic and Trade Agreement deal with China, ${ }^{35}$ although not cancelling many of the previously imposed tariffs - which adds to the puzzling and controversial debate on EU-China-US tripolar geopolitical dynamics and cast worries on the European side.

China agreed to increase its imports (on specific products) from the US in the coming two years, which will directly impact other countries' exports to China, while the remaining US' tariffs on Chinese goods will mean redirecting these products to other markets, including the EU market. Broadly speaking, the overall US' trade deficit with Beijing will not lower because of implementing the commercial agreement, as larger macroeconomic policies' implications account for the main driver of change in this regard. ${ }^{36}$

Additionally, experts' opinions conflict over who has managed to attain specific leverage over the other by signing Phase-One deal. Some view the agreement as a small gain for China at first sight and a continuous dependency on US exports, while others state that it actually gives the Chinese trading partner "the upper hand", since purchase commitments sealed under bilateral understanding disobey free market principles and the broader rules-based trading architecture, bearing strategic, systemic costs for the US. That is, Washington faces the risk of slowly undermining its potential of global economic leadership, at the expense of a constantly evolving, state-led Chinese dirigiste model of economic growth. ${ }^{37}$

${ }^{35}$ Economic And Trade Agreement Between The Government Of The United States Of America And The Government Of The People's Republic Of China, https://ustr.gov/ sites/default/files/files/agreements/phase\%20one\%20agreement/Economic_And_Trade_ Agreement_Between_The_United_States_And_China_Text.pdf (access 15.03.2020).

36 B. Hofman, Commentary: Why China signed an unequal trade deal with the US, "Channel News Asia", 14.02.2020, https://www.channelnewsasia.com/news/commentary/china-us-trade-war-deal-agreement-phase-1-2-tariff-coronavirus-12417824 (access 15.03.2020).

37 J.P. Meltzer, N. Shenai, Why the purchase commitments in the US-China trade deal should not be replicated, ever, "Brookings Report", 4.02.2020, http://www.brookings.edu/ blog/up-front/2020/02/04/why-the-purchase-commitments-in-the-us-china-trade-dealshould-not-be-replicated-ever (access 15.03.2020). 
Drawing parallels between the EU and the US' stance on China, it seems that both feared the other's tightening relations with Beijing, the reasons being similar, gravitating around Chinese geopolitical advantage and the preoccupation for renewing transatlantic ties decreased in intensity (especially on the American side).

Moreover, amidst the worldwide crisis generated by the coronavirus, the international community dedicated its attention and resources mainly to this humanitarian and economic cause, while other issues fell to the second place. Therefore, implementing US-China Phase-One deal - and preparing for a second round of trade talks - or negotiating a commercial agreement between Europeans and Americans face all the premises to be stalled for the moment, especially as President Donald Trump framed the new turmoil as originating in a "Chinese virus", much to the Asians' discontent, though he wanted to make it clear that this is not a racist terminology, but simply referring to the place the pandemic busted. The allegation also comes as a response to several Chinese officials' conspiracy theories that the COVID-19 illness began in the U.S. or was brought to China by the U.S. Army, during the October 2019 Military World Games in Wuhan. China's new Foreign Ministry spokesman, Zhao Lijian questioned this possibility in a tweet on March 12, 2020. ${ }^{38}$ Added to these, President Trump' immediate measure to impose travel restrictions to Europe on March 12 waned again Brussels' trust in the old transatlantic partner.

In the whole framework of interdependent consequences within the international, interconnected system, the coronavirus pandemic presented China in other denominations as a propagandistic "global saviour", devastating European and American involvement and deepening the transatlantic gap, although resentments and doubts about China's initial handling of the crisis still represent a source of anger and mistrust for Beijing's overseas partners.

The Chinese government is trying to "establish itself as a global hero that saved many people both in and outside China," remarks Lee Seonghyon, director of the Center for Chinese Studies at the Sejong Institute in Seoul in an interview for Foreign Policy. ${ }^{39}$ "China's coming out strong

38 A. Panda, Chinese Foreign Ministry Spokesperson Implies US Military Brought Coronavirus to Wuhan, "The Diplomat", 13.03.2020, https://thediplomat.com/2020/03/ chinese-foreign-ministry-spokesperson-implies-us-military-brought-coronavirus-to-wuhan/ (access 15.03.2020).

39 M. Soendergaard Larsen, R. Gramer, China Casts Itself as Global Savior While U.S. and EU Focus on Virus at Home, „Foreign Policy”, 19.03.2020, https://foreignpolicy. com/2020/03/19/china-us-eu-coronavirus-great-power-competition/ (access 20.03.2020). 
with its PR, sensing, correctly, that this global epidemic is also a great opportunity to burnish China's soft power credentials with Europe and [others]. On the other hand, America is not investing enough resources to help its traditional allies and friends, and not investing enough in this narrative war". ${ }^{40}$

\section{Conclusions}

The transatlantic gap is enlarging further as new challenges appear, affecting the functioning of the international system. Biological (as well as economic) risks posed by the ongoing crisis around the worldwide spread of the coronavirus add to the already distorted political and diplomatic dialogue between Brussels and Washington.

Furthermore, the crisis is challenging third parties' position, as China faces the major blame for this pandemic, losing trust in both Europeans and Americans' perception.

In the last years, China rose as an influential global actor, boosting its economic, technological and military power and offering transactional alternatives to status-seeker, world powers like the EU and the US. Both engaged in constantly monitoring the other's rapprochement to China, they feared consequences of Beijing's expansionism and its geopolitical alternative, nevertheless preferring their own bilateralism with the Asian partner, detrimental to an investment in transatlantic cooperation.

The gradual disruption in EU-US commercial and security relations was supported by the emotional leadership that President Donald Trump has been practising during his first term in office. His political discourse and the decisions he has made unveiled an idiosyncratic approach that was shaped by a specific, psychological model of decision-making, marked by cognitive distortions impacting upon his “opponents' susceptibility towards American persistent commitment to the Western cause".

The advisory system, bearing a longstanding tradition in the US presidential history, remains a fact in the Trump administration, but its overall capacity to influence foreign policy decisions reaches an average level. Cabinet advisers often engage in competitive rhetoric over problematic issues, trying to pursue the leader's final say but, as President Trump himself put it, in the end, he does what he feels right to do.

A rising China could be an argument for the potential assertiveness of illiberal, undemocratic values within the international community, undermining the stability of transatlantic alliance and its adherents. The fact that both the EU and the US perceived China as challenging current

${ }^{40}$ Ibidem. 
geopolitics but still, they accepted the invitation for pursuing partnership could come at a serious cost for the democratic world order in the not-toodistant future.

\section{References}

Amaro S., It's 'complicated to negotiate with the European Union,' Wilbur Ross says, “CNBC", 17.06.2019, https://www.cnbc.com/2019/06/17/its-complicatedto-negotiate-with-the-eu-wilbur-ross-says.html (access 21.03.2020).

Barkin N., Europe's moment of truth with China. 6 factors that will shape the Continent's relationship with Beijing in 2020, "Politico", 13.01.2020, https://www.politico.eu/article/europes-moment-of-truth-with-chinatrade-eu/ (access 13.03.2020).

Campanale F., Shakun B., Behavioral Idiosyncracies and How They May Affect Investment Decision, "American Association of Individual Investors Journal", vol. XIX, no. 9/1997.

Ciot M.G., Idiosyncrasies In Trump's Foreign Policy Decision Making, in: Analele Universității din Oradea, ed. Mircea Brie, University of Oradea, Oradea 2016.

Ciot M.G., Negotiation and Foreign Policy Decision-Making, Cambridge Scholars, Newcastle upon Tyne 2014.

Donnan S., Trump's top trade adviser accuses Germany of currency exploitation, "Financial Times", 31.01.2017, https://www.ft.com/content/57f104d2e742-11e6-893c-082c54a7f539 (access 21.03.2020).

Economic And Trade Agreement Between The Government Of The United States Of America And The Government Of The People's Republic Of China, https://ustr.gov/sites/default/files/files/agreements/phase $\% 20$ one\%20agreement/Economic_And_Trade_Agreement_Between The_United_States_And_China_Text.pdf (access 15.03.2020).

Fagen $\bar{R} . R .$, Calculation and emotion in foreign policy: the Cuban Case, "Journal of Conflict Resolution", vol. VI, no. 3/1962, DOI: https://doi. org/10.1177/002200276200600303.

Fishel J., Mike Flynn Says He Helped Shape Trump's Views on NATO, “ABC News", 19.11.2016, https://abcnews.go.com/Politics/mike-flynn-helpedshape-trumps-views-nato/story?id $=43642585$ (access 21.03.2020).

Garber J., Langford J., Europe has 'sense of panic' over securing US trade deal: Wilbur Ross, "Fox Business", 23.01.2020, DOI: https://doi.org/10.11606/ issn.2176-1507.v21ilp03-11.

Ghidiu I.A., Reinventarea Drumului Mătăsii, “Economistul”, 28.09.2016, https://www.economistul.ro/cover/reinventarea-drumului-matasii-733/ (access 13.03.2020). 
Hofman B., Commentary: Why China signed an unequal trade deal with the US, "ChannelNewsAsia", 14.02.2020, https://www.channelnewsasia. $\mathrm{com} /$ news/commentary/china-us-trade-war-deal-agreement-phase-12-tariff-coronavirus-12417824 (access 15.03.2020).

Hogan P., Refreshing Transatlantic Trade Relations, Keynote Address at Centre for Strategic and International Studies (CSIS), Washington DC, 16.01.2020, http://ec.europa.eu/commission/commissioners/20192024/hogan/announcements/refreshing-transatlantic-relationskeynote-address-commissioner-phil-hogan-centre-strategic-and_en (access 12.01.2020).

Jackson R., Sorensen G., Introduction to International Relations. Theories and approaches, Oxford University Press, Oxford 2007.

Kaplan T., Kudlow: Phase One of China trade deal is 'historic' and will help US economy grow faster, "Fox News", 15.01.2020, https://www.foxnews.com/ media/larry-kudlow-china-trade-deal-defends-american-economy (access 21.03.2020).

Karnitschnig M., Donald Trump leaves Europe in the cold, "Politico", 20.01.2017,http://www.politico.eu/article/donald-trump-leaves-europein-the-cold-in-inauguration/ (access 14.03.2020).

Karnitschnig M., Europe turns deaf ear to US warnings on Chinese $5 G$. Washington warns its allies that Huawei is a Trojan horse for Beijing's expansion plans, "Politico", 15.02.2020, https://www.politico.eu/article/ u-s-chides-europe-on-china-tech-risks/ (access 13.03.2020).

Kowert P.A., Groupthink or Deadlock: When Do Leaders Learn from Their Advisors?, State University of New York Press, Albany, NY 2002.

Lucas J., U.S. President Donald Trump on his decision-making process: "I don't think about it", "The Georgia Straight", 19.11.2018, https://www. straight.com/news/1166066/us-president-donald-trump-his-decisionmaking-process-i-dont-think-about-it (access 21.03.2020).

McAdams D.P., The Mind of Donald Trump, "The Atlantic", 2016, http:// www.theatlantic.com/magazine/archive/2016/06/the-mind-of-donaldtrump/480771/ (access 14.03.2020).

Meltzer J.P., Shenai N., Why the purchase commitments in the US-China trade deal should not be replicated, ever, "Brookings Report", 4.02.2020, http:// www.brookings.edu/blog/up-front/2020/02/04/why-the-purchasecommitments-in-the-us-china-trade-deal-should-not-be-replicatedever (access 15.03.2020).

Noack R., Now that Trump has a trade deal with China, some Europeans fear he will focus his trade threats on them, "Washington Post", 17.01.2020, https://www.washingtonpost.com/world/2020/01/17/now-that-trump- 
has-trade-deal-with-china-some-europeans-fear-he-will-focus-histrade-threats-them/ (access 14.03.2020).

Owen D., Hubris, the road to Donald Trump. Power, populism and narcissism, Methuen, York 2018.

Panda A., Chinese Foreign Ministry Spokesperson Implies US Military Brought Coronavirusto Wuhan, “The Diplomat", 13.03.2020, https://thediplomat. com/2020/03/chinese-foreign-ministry-spokesperson-implies-usmilitary-brought-coronavirus-to-wuhan/ (access 15.03.2020).

Preston T., The President and His Inner Circle: Leadership Style and the Advisory Process in Foreign Affairs, Columbia University Press, New York 2001, DOI: https://doi.org/10.7312/pres11620.

Rappeport A., Swanson A., Peter Navarro, Trump's Trade Warrior, Has Not Made His Peace With China, "The New York Times", 26.12.2019, DOI: https://doi.org/10.11606/issn.2176-1507.v21ilp03-11.

Rios B., Von der Leyen and Trump fine tune transatlantic relations in Davos, "Euractiv", 21.01.2020, https://www.euractiv.com/section/economyjobs/news/von-der-leyen-and-trump-fine-tune-transatlantic-relationsin-davos/ (access 12.03.2020).

Shalal A., Lawder D., As Trump takes aim at EU trade, European officials brace for fight, "Reuters", 11.02.2020, https://www.reuters.com/article/ususa-trade-europe-analysis/as-trump-takes-aim-at-eu-trade-europeanofficials-brace-for-fight-idUSKBN2051AK (access 12.03.2020).

Skala-Kuhmann A., European Responses to BRI. An overdue assessment, "Horizons-Journal of International Relations and Sustainable Development", no. 14/2019.

Soendergaard L., Robbie G.M., China Casts Itself as Global Savior While U.S. and EU Focus on Virus at Home, "Foreign Policy", 19.03.2020, https://foreignpolicy.com/2020/03/19/china-us-eu-coronavirus-greatpower-competition/ (access 20.03.2020).

Trump D.J., Great Again: How to Fix Our Crippled America, Threshold Editions, Reprint edition, 2016. 